\begin{tabular}{|ll|}
\hline Received & $: 7$ May 2019 \\
Revised & $: 24$ May 2019 \\
Accepted & $:$ 11 June 2019 \\
Published & $:$ 30 June 2019
\end{tabular}

\title{
The Use of Spatial and Temporal Deixis in The Narrative Essay Written by X Grade Students of Wira Buana 2 Vocational High School
}

\author{
Chadis ${ }^{1, a)}$ \\ Program Studi Pendidikan Bahasa Indonesia, Fakultas Bahasa dan Seni, \\ Universitas Indraprasta PGRI, Jakarta, Indonesia \\ E-mail: ${ }^{\text {a) }}$ chadis_cila@yahoo.com
}

\begin{abstract}
This study aimed to determine the use of spatial and temporal deixis that used in narrative essays written by X grade students Wira Buana 2 Vocational High School. This study use qualitative descriptive approach followed by content analysis technique. Based on the results of the analysis that has been carried out, there are as many as 130 usage of spatial and temporal deixis findings. These findings consist of 66 findings of spatial deixis (50.77\%) and 64 findings of temporal deixis $(49.23 \%)$. This result indicate that the use of spatial and temporal deixis are equally dominant in narrative essays written by X grade students of Wira Buana 2 Vocational High School.
\end{abstract}

Keywords: spatial deixis, temporal deixis, narrative essay

\begin{abstract}
Abstrak
Penelitian ini bertujuan untuk mengetahui penggunaan deiksis tempat dan waktu yang terdapat dalam karangan narasi siswa Kelas X Sekolah Menengah Kejuruan (SMK) Wira Buana 2. Penelitian ini menggunakan pendekatan deskriptif kualitatif dengan teknik analisis isi. Berdasarkan hasil analisis yang telah dilakukan, terdapat sebanyak 130 temuan deiksis waktu dan tempat. Temuan tersebut dengan perincian deiksis tempat sebanyak 66 temuan (50.77\%) dan deiksis waktu sebanyak 64 temuan (49.23\%). Hal tersebut menandakan bahwa penggunaan deiksis tempat dan deiksis waktu sama-sama dominan dalam karangan narasi siswa Kelas X Sekolah Menengah Kejuruan (SMK) Wira Buana 2.
\end{abstract}

Kata kunci: deiksis tempat, deiksis waktu, karangan narasi 


\section{PENDAHULUAN}

Menulis merupakan salah satu keterampilan berbahasa. Keterampilan ini menjadi penting karena perlu dibiasakan. Dalam hal ini, peranan guru bahasa Indonesia dalam mengajar di kelas menjadi satu hal penting yang dapat melatih siswa dalam menulis karangan, salah satunya adalah penggunaan deiksis.

Deiksis berasal dari bahasa Yunani, yaitu deiktitos yang berarti 'hal penunjukan secara langsung.' Deiksis berakar pada persona pertama tunggal dan menyangkut persona, waktu dan ruang, atau tempat (Verhaar, 2006). Sejalan dengan pernyataan tersebut, Kridalaksana (2009) berpendapat, "deiksis adalah hal atau fungsi yang menunjuk sesuatu di luar bahasa yang menyangkut persona waktu dan ruang." Dalam Kamus Besar Bahasa Indonesia (2011), deiksis berarti hal atau fungsi menunjuk sesuatu di luar bahasa; kata yang mengacu kepada persona, waktu, dan tempat suatu tuturan.

Putrayasa (2014) berpendapat, "deiksis adalah kata yang tidak memiliki referen atau acuan yang tetap." Lalu, menurut Alwi, Lapoliwa, dan Darmowijojo (2003), "deiksis adalah gejala semantis yang terdapat pada kata atau konstruksi yang hanya dapat ditafsirkan acuannya dengan memperhitungkan situasi pembicara." Pendapat lain juga diungkapkan oleh Yule (1996) yang menyatakan "deiksis berarti penunjukan melalui bahasa". Deiksis dapat dipahami sebagai suatu istilah yang merujuk pada kata atau frasa yang tidak dapat dipahami tanpa adanya informasi kontekstual (Abdulameer, 2019). Dengan demikian, dapat disimpulkan bahwa deiksis adalah bahasa yang memiliki referen atau acuan yang dapat berubah-ubah atau tidak tetap, yang hanya dapat ditafsirkan acuannya dengan memperhatikan situasi pembicaraan.

Kushartanti, Yuwono, dan Lauder (2005) juga berpendapat "deiksis adalah cara merujuk pada suatu hal yang berkaitan erat dengan konteks penutur. Dengan demikian, ada rujukan yang berasal dari penutur, dekat dengan penutur dan jauh dari penutur." Deiksis menunjukkan cara di mana bahasa mengodekan atau menggramatikalkan unsurunsur dari konteks ujaran atau peristiwa tutur dan karena itu juga menunjukkan caracara di mana interpretasi terhadap ujaran bergantung pada analisis terhadap konteks ujaran itu (Putrayasa, 2014; Suhartatik, 2018).

Deiksis termasuk ke dalam ranah pragmatik karena deiksis secara langsung mengacu kepada hubungan antara struktur bahasa dan konteks deiksis itu digunakan. Selain itu, deiksis meliputi banyak petunjuk tentang tempat, persona, dan waktu berkaitan dengan konteks penggunaannya. Tanpa adanya konteks, deiksis dapat membingungkan orang atau dapat menimbulkan ambiguitas.

Deiksis adalah kata tertentu yang kadang-kadang disertai dengan perbuatan tingkah laku pembicara berupa gestur atau mimik muka untuk menyatakan makna kata yang diucapkan lebih jelas (Ihsan, 2011; Purwahida, 2017; Purwahida, 2018). Pada saat menggunakan deiksis seperti ini, itu, saya, kamu, di sana, sekarang dan lain sebagainya, seseorang dapat mengucapkannya dengan tanda berupa anggota tubuh seperti tangan, jari, dan kepala. Misalnya, seseorang memanggil orang lain, tetapi orang yang dipanggil itu masih ragu apakah dirinya dipanggil atau tidak. Oleh karena itu, orang tersebut akan bertanya saya? kepada orang tersebut dengan menggunakan tangan atau jari yang menunjuk ke arah dirinya. Begitu pun dengan kata ini dan di sana yang memungkinkan seseorang menunjuk benda atau tempat.

Ketika seseorang berkata "kamus ini", maka orang tersebut telah menggunakan ungkapan deiksis ini untuk menunjuk sesuatu. Dalam kegiatan berbahasa, terdapat kata atau frasa yang mengacu pada suatu hal yang sudah pasti atau dapat dibayangkan, 
misalnya kata kamus. Kamus sudah pasti berisikan pengertian dari suatu hal dan identik dengan buku yang tebal. Berbeda dengan kata ini. Seseorang tidak akan dapat membayangkannya dengan pasti. Jadi, kata seperti ini disebut penunjuk di luar bahasa.

Deiksis dapat digunakan dalam semua jenis karangan, tidak terkecuali karangan narasi. Karangan narasi adalah karangan cerita yang di dalamnya terdapat tokoh dan alur. Karangan narasi menjadi bagian terpenting pula dalam pembelajaran menulis karena karangan narasi dapat digunakan untuk menceritakan sebuah kisah.

Deiksis memiliki beragam jenis. Namun, penelitian ini hanya berfokus pada deiksis tempat dan deiksis waktu. Dalam sebuah tuturan, sering kita temukan penggunaan deiksis tersebut, misalnya, "Di sini tidak hujan," kata si A yang tinggal di Kota Depok. Lalu, si B yang tinggal di Bekasi pun berkata, "Di sini juga tidak hujan." Makna di sini yang diungkapkan oleh si A dan si B berbeda. Berdasarkan uraian di atas, penelitian ini membahas deiksis tempat dan deiksis waktu. Hal ini dianggap menarik karena para siswa tidak menyadari bahwa dalam karangan yang mereka buat terdapat banyak penggunaan deiksis tersebut.

\section{METODE PENELITIAN}

Penelitian ini menggunakan pendekatan deskriptif kualitatif. Dengan pendekatan tersebut, penulis melakukan kajian langsung terhadap penggunaan deiksis waktu dan tempat pada karangan narasi siswa kelas X di SMK Wira Buana 2. Pengambilan data dilakukan saat kegiatan pembelajaran bahasa Indonesia di kelas sesuai dengan jam pelajaran. Teknik yang digunakan dalam penelitian ini adalah teknik analisis isi. Analisis isi ini digunakan karena penulis berusaha untuk mengumpulkan dan menganalisis data dari karangan narasi yang telah dibuat oleh siswa sehingga penulis hanya berkonsentrasi pada isi dari karangan tersebut.

\section{HASIL DAN PEMBAHASAN}

Berdasarkan pengklasifikasian dan analisis data, terdapat 130 temuan deiksis waktu dan deiksis tempat. Secara rinci, temuan berupa deiksis tempat adalah sebanyak 66 temuan $(50.77 \%)$ dan temuan deiksis waktu sebanyak 64 temuan $(49.23 \%)$.

TABEL 1. Temuan Penelitian

\begin{tabular}{lrr}
\hline DeiksisTempat & 66 & $50.77 \%$ \\
\hline DeiksisWaktu & 64 & $49.23 \%$ \\
\hline Total Temuan & 130 & $100 \%$ \\
\hline
\end{tabular}

DIAGRAM 1. Temuan Penelitian

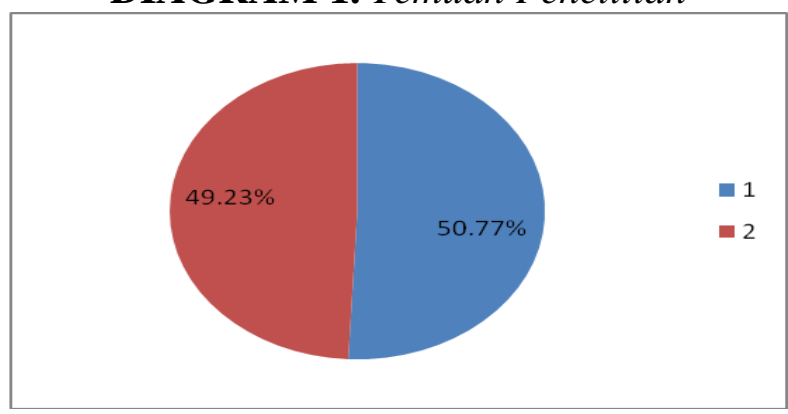




\section{Deiksis Tempat}

Deiksis tempat berkaitan dengan kata-kata yang merujuk pada lokasi tertentu dan bersifat relatif terhadap penutur dan lawan tutur dalam suatu ujaran (Ekowati \& Sofwan, 2014; Khalili, 2017). Berdasarkan hasil penelitian, terdapat deiksis tempat yang digunakan oleh siswa kelas X SMK Wira Buana 2, yaitu di sini, di sana, ke sana, sini, $i t u$, dan ini. Kata di sana dan di sini adalah deiksis tempat. Kedua kata tersebut samasama menunjukan suatu tempat atau lokasi tetapi memiliki perbedaan. Jika kata di sini memiliki acuan yang dekat dengan diri penulis, kata di sana memiliki acuan yang jauh dari diri penulis. Begitu pula kata situ yang menunjukan lokasi tertentu. Hal tersebut sesuai dengan pandangan dari Verhaar (2006) yang menyatakan bahwa pronomina ini mengacu pada sesuatu yang ada di tempat penutur. Sebaliknya, itu mengacu pada sesuatu tempat yang bukan tempat penutur.

Di bawah ini merupakan kutipan dari hasil karangan narasi siswa yang menggunakan kata-kata deiksis tersebut, yaitu sebagai berikut.

1. Di sana rencananya kami hanya ingin main petak umpat.

2. Aku dan teman-teman tidak ingin berlibur lagi ke sini dikarenakan hal tersebut, sungguh liburan yang tak terlupakan.

3. Di sana kami merasa bahagia karena kami bisa merasakan wahana-wahana yang menyenangkan.

4. Besoknya keluarga saya dan keluarga saya pergi jalan-jalan ke Yogyakarta, di sana saya ke Candi Perambanan dan Malioboro, dan di sana saya poto-poto dan membeli oleh-oleh untuk saudara saya yang ada di Jakarta, selama saya di Solo saya selalu diajak jalan-jalan sama saudara saya.

5. Hanya sampai situ saja cerita saya, terima kasih.

6. Ya sudahlah kita pulang saja, kalau tidak ke rumah teman saya saja yang dekat-dekat dari sini.

Kata ini dan itu termasuk dalam deiksis tempat. Namun, kedua deiksis tersebut memiliki sifat yang istimewa yaitu demonstratif. Kata ini memiliki acuan yaitu tempat atau menunjuk sesuatu seperti benda atau peristiwa yang dekat dengan penulis, sedangkan kata itu memiliki arti sebaliknya. Hal tersebut sesuai dengan pandangan dari Putrayasa (2014) yang menyatakan bahwa contoh kata penunjuk tempat adalah ini, itu, dan апи. Berikut ini merupakan kutipan dari hasil karangan narasi yang menggunakan kata-kata deiksis tersebut.

1. Klub kebanggaan saya itu PERSIB Bandung.

2. Kami berjalan-jalan melihat indahnya bunga-bunga, tapi kami tidak sengaja menginjak bunga yang indah itu.

3. Hari demi hari berlalu, tak terasa sepi di rumah karena sepupuku yang riang ini.

4. Rencana ini sudah kami persiapkan jauh sebelum liburan semester, tepatnya ketika kami sedang UTS.

\section{Deiksis Waktu}

Deiksis waktu adalah deiksis yang merujuk pada informasi yang menunjukkan titik watu atau rentang waktu ketika suatu ujaran diucapkan (Anggara, 2017). Deiksis waktu dapat dibedakan berdasarkan hubungan waktu, periode waktu, dan momen ketika ujaran diucapkan (Wahyudi, 2014). Berdasarkan hasil penelitian, deiksis waktu yang 
digunakan oleh siswa kelas X SMK Wira Buana 2 adalah kemarin, bulan yang lalu, minggu yang lalu, semester yang lalu, saat itu, waktu itu, pagi ini, pagi itu, hari itu, suatu hari, ketika, setelah itu, besok, hari-hari berikutnya, hari demi hari berlalu, dan berselang beberapa jam. Dalam penulisan hasil karangan yang telah dibuat siswa, terdapat deiksis waktu yang menunjukkan waktu sebelum terjadinya ujaran seperti kata kemarin. Kata kemarin mengacu pada hari sebelum hari ini. Hal tersebut sesuai dengan pandangan dari Putrayasa (2014) yang menyatakan bahwa waktu sebelum waktu terjadinya ujaran kita menemukan kata kemarin. Berikut merupakan karangan yang menggunakan deiksis kemarin.

1. Pada hari Selasa kemarin, saya bersama teman-teman berlibur ke Bandung dengan naik bus.

2. Pada hari libur kemarin, saya dan keluarga saya pergi ke desa mengunjungi nenek yang ada di desa.

3. Pada hari Senin, tepatnya kemarin saya dan keluarga berlibur ke Monumen Nasional atau disingkat dengan kata Monas.

4. Pada liburan semester kemarin, tepatnya bulan Desember, saya dan ketiga teman saya berlibur ke Taman Bunga Nusantara yang berada di kawasan Cipanas, Puncak.

Kata minggu lalu, bulan lalu, dan semester yang lalu termasuk dalam kategori deiksis waktu. Kata minggu lalu, bulan lalu, atau semester yang lalu dalam karangan siswa dapat menunjukan kejadian satu minggu yang lalu, satu bulan yang lalu, atau satu semester yang lalu yang pernah mereka alami. Deiksis-deiksis tersebut dapat dilihat dalam kutipan karangan berikut.

1. Minggu lalu, aku dan teman-temanku pergi ke Pulau Tidung untuk berlibur.

2. Pada bulan yang lalu, saya dan keluarga saya pergi ke Bandung menonton tim kesayangan saya yaitu bernama Persib Bandung.

3. Liburan semester yang lalu, saya tidak pergi ke mana-mana.

Pagi ini termasuk dalam deiksis waktu. Deiksis tersebut mengacu pada pagi yang sedang berlangsung dalam karangan siswa. Deiksis tersebut ditemukan dalam satu karangan narasi siswa berikut, "Pagi ini terlihat sangat sibuk, di jalan terlihat ibu-ibu yang sedang menuju pasar untuk berjualan sayuran."

Saat itu, waktu itu, hari itu, dan pagi itu termasuk kategori deiksis waktu. Deiksisdeiksis tersebut menunjukan waktu kejadian atau pengalaman siswa yang sudah pernah terjadi. Hal ini sesuai dengan pandangan dari Putrayasa (2014) yang menyatakan bahwa waktu ketika terjadinya ujaran kita menemukan kata saat ini. Berikut merupakan kutipan pada karangan siswa yang menggunakan deiksis tersebut.

1. Pada saat itu, posisi saya sedang berada di tempat kopdaran saya, IVS (Indonesia Variant Style).

2. Pada hari itu, pada tanggal 16 April 2017, saya bersama kawan-kawan saya berlibur ke Kota Tua Jakarta.

3. Udara yang sejuk dan pemandangan yang indah membuat saya mengingat masa lalu di mana waktu itu umur saya masih tujuh tahun, saya mengunjungi rumah nenek.

4. Saya dan keluarga tidak akan melupakan acara makan di Goeboek Bamboe pada sore hari itu.

Besok dan keesokan harinya termasuk dalam deiksis waktu. Penggunaan deiksis tersebut dalam karangan siswa mengacu pada hari setelah hari ini. Penggunaan deiksis 
besok dan keesokan harinya dapat dilihat pada kutipan karangan narasi siswa berikut.

1. Kata teman saya ya sudahlah, besok saja kita pulang, pagi pun tiba.

2. Keesokan harinya, aku diajak keponakan ayah untuk pergi ke sawah nenek.

3. Besoknya, saya dan keluarga saya pergi jalan-jalan ke Yogyakarta, di sana saya ke Candi Perambanan dan Malioboro, dan di sana saya poto-poto dan membeli oleholeh untuk saudara saya yang ada di Jakarta, selama saya di Solo saya selalu diajak jalan-jalan sama saudara saya.

Hari-hari berikutnya, hari demi hari berlalu, berselang beberapa jam, setelah itu merupakan deiksis waktu. Deiksis-deiksis tersebut mengacu pada waktu yang akan datang. Hari-hari berikutnya dan hari demi hari berlalu menunjukan dua bahkan lima hari serta berselang beberapa jam dapat menunjukan dua, lima bahkan dua puluh jam, sehingga waktu yang dimaksud penulis belum diketahui pasti oleh pembaca. Dengan kata lain, hanya penulis sendiri yang tahu. Hal tersebut sesuai dengan pandangan dari Putrayasa (2014) yang menyatakan bahwa waktu sebelum waktu terjadinya ujaran berarti menggunakan deiksis minggu lalu. Begitu pun dengan setelah itu. Namun, kata setelah itu mengacu pada waktu yang tidak terlalu lama. Berikut adalah beberapa penggunaan deiksis-deiksis tersebut pada karangan siswa.

1. Hari-hari berikutnya, aku diajak keponakan ayah untuk pergi ke sawah nenek.

2. Berselang beberapa jam, saya sampai juga di Bandung, tetapi setelah saya sampai di Bandung pertandingan belum dimulai, dan saya menyempatkan berkeliling di luar area studion.

3. Hari demi hari berlalu, tak terasa sepi di rumah karena sepupuku yang riang ini.

4. Setelah itu, saya pergi melihat harimau dan juga singa.

\section{KESIMPULAN}

Berdasarkan hasil analisis yang telah dilakukan pada karangan narasi yang ditulis oleh siswa kelas X SMK Wira Buana 2, terdapat 130 temuan deiksis waktu dan deiksis tempat. Temuan tersebut menghasilkan perincian deiksis tempat sebanyak 66 temuan $(50,77 \%)$ dan deiksis waktu sebanyak 64 temuan $(49,23 \%)$. Hal tersebut menandakan bahwa penggunaan deiksis tempat dan deiksis waktu sama-sama dominan dalam karangan narasi siswa kelas X Sekolah Menengah Kejuruan (SMK) Wira Buana 2.

\section{UCAPAN TERIMA KASIH}

Ucapan terima kasih disampaikan kepada Yayasan Nurul Hakim Lombok, Program Pendidikan Khusus Kulliaytul Muallimin, dan Muallimat al-Islamiyah yang telah berkontribusi banyak dalam penelitian ini.

\section{REFERENSI}

Abdulameer, T.A.S.A. (2019). A pragmatic analysis of deixis in a religious text. International Journal of English Linguistics, 9(2), 292-306. doi:10.5539/ijel.v9n2p292 
Alwi, H., Lapoliwa, H., \& Darmowijojo, S. (2003). Tata Bahasa Baku Bahasa Indonesia Cetakan Ke-5. Jakarta: Balai Pustaka.

Anggara, I.G.A. (2017). Deixis used in top five Waldjinah's popular keroncong song lyrics. PAROLE: Journal of Linguistics and Education, 6(1), 35-42. doi: https://doi.org/10.14710/parole.v6i1.35-42

Departemen Pendidikan Nasional. (2011). Kamus Besar Bahasa Indonesia. Jakarta: PT Gramedia.

Ekowati, A., \& Sofwan, A. (2014). The use of pragmatic deixis in conversation texts in pathway to English. Lembar Ilmu Kependidikan: Journal of Educational Research, 43(2), 71-77.

Ihsan, D. (2011). Pragmatik, Analisis Wacana, dan Guru Bahasa. Palembang: Universitas Sriwijaya.

Khalili, E. (2017). Deixis analysis in A Tale of Two Cities written by Charles Dickens. International Academic Journal of Social Sciences, 4(3), 58-65.

Kridalaksana, H. (2009). Kamus Linguistik. Jakarta: Gramedia Pustaka Utama.

Kushartanti, Yuwono, U., \& Lauder, M.R.M.T. (2005). Pesona Bahasa: Langkah Awal Memahami Bahasa. Jakarta: Gramedia Pustaka Utama.

Purwahida, R. (2017). Interaksi sosial pada kumpulan cerpen Potongan Cerita di Kartu Pos karangan Agus Noor dan implikasinya terhadap pembelajaran sastra di SMA. Aksis: Jurnal Pendidikan Bahasa dan Sastra Indonesia 1(1). 118-134. doi: doi.org/10.21009/AKSIS.010107

Purwahida, R. (2018). Problematika Pengembangan Modul Pembelajaran Baca Tulis Anak Usia Sekolah Dasar. Aksis: Jurnal Pendidikan Bahasa dan Sastra Indonesia 2(1). 118-134. doi: doi.org/10.21009/AKSIS.020108

Putrayasa, I.B. (2014). Pragmatik. Yogyakarta: Graha Ilmu.

Suhartatik. (2018). Makna Leksikal Bahasa Madura Keadaan Alam Nelayan di Pesisir Kepulauan Sumenep. Aksis: Jurnal Pendidikan Bahasa dan Sastra Indonesia 2(1). 107-126. doi: doi.org/10.21009/AKSIS.020107

Verhaar, J.W.M. (2006). Asas-Asas Linguistik Umum. Yogyakarta: Gajah Mada University Press.

Wahyudi. (2014). Pragmatics study on deixis in the Jakarta Post editorial. Jurnal Penelitian Humaniora, 15(2), 111-120. doi: https://doi.org/10.23917/humaniora.v15i2.758

Yule, G. (1996). Pragmatics. London: Oxford. 